\title{
The Kiss of the Shekhinah: Narratives of Human and Divine Motherhood in the Holocaust ${ }^{1}$
}

\author{
MELISSA RAPHAEL \\ University of Gloucestershire
}

\begin{abstract}
During the Holocaust Jewish mothers and their children were treated by the Nazis not as non-combatants but as enemies posing a direct racial threat to the Reich. This paper will use the recent research into gender and the Holocaust and oral histories of mothers and daughters who survived the Holocaust to show how women experienced and resisted that status as "enemies" of the Reich. And more to the theological point, this paper will explore how those mothers' suffering and resistance to their own and their children's suffering signals towards another model of covenantal relation between God and Israel where God's promise to Israel in Leviticus 26: "I will be ever in your midst; I will be your God, and you shall be My people" need no longer be figured in terms of loyalty and obedience to the commandment of an overbearing Lord.
\end{abstract}

Keywords: Judaism, motherhood, Holocaust, gender, oral history, suffering, resistance.

This paper will use the notion of the Motherhood of God in Auschwitz that I proposed in my book The Female Face of God in Auschwitz (2003) in order to suggest that an alternative feminist model of female love, power and providence does resist evil, that, in particular, the power of motherhood is not merely a sentimental bourgeois idea beloved of first wave religious feminism, but that it could be resilient, resourceful, resistant, that in extremis the maternal resistance of mothers and quasi-mothers helped women and

\footnotetext{
${ }^{1}$ This article combines parts of my book The Female Face of God in Auschwitz: A Jewish Feminist Theology of the Holocaust. London and New York, Routledge (2003), with further research completed after the publication of the book.
} 
children to survive the Nazi assault spiritually and occasionally physically as well.

This is important to the post-Holocaust project because to be faithful to the actual and historically particular suffering of all persons during the Holocaust and to the covenantal presence of God in the midst of that suffering, it must reflect on the gendered variety of Jewish experience. ${ }^{2}$ It cannot proceed, as it has usually done, as if the suffering of mothers and children has offered a graphic illustration of Nazi barbarism, but not insight into God. In fact, the theology presented in this paper may be feminist, but its method is fairly traditional: Judaism is traditionally reluctant to merely theorise God, rather the presence of God is detected and articulated in the given historical situation.

To begin, then, by reflecting on the opening years of that historical situation: As Nechama Tec has pointed out, ironically, because of their consistently subordinate roles, mothers may have been more adaptable to traumatic change than fathers (Tec 2003, 10). In the early days of the Nazi occupation when men were publicly humiliated with beatings and other tortures and robbed of their livelihoods, they tended to succumb to depression and "gave up". Even though very few would be ultimately successful in their efforts, wives then had to use their flexibility and resourcefulness to organise the family into a unit that could survive or at least continue to eat (Tec 2003, 26, 349). Theirs was an especially demanding situation in that they had, in such cases, lost the traditional means of emotional and usually financial support from the man who had been the head of the family.

Of course, after the deportations to death and concentration camps had begun, women's circumstances, already dire, deteriorated sharply. When relatively young mothers had teenage daughters and no other young chil-

\footnotetext{
${ }^{2}$ It must not be forgotten that Jews' experience of the Holocaust varied greatly according to the different periods and locations of the genocide. In Finland, for example, Jews were somewhat less at risk than in countries like Latvia and Poland. Mannerheim refused Himmler's demand that he deport about 1000 Finnish Jews. Jewish Finnish men served in the Finnish army, although Finland fought alongside the German Wehrmacht from June 1941 to summer 1944 when an armistice was signed with the Soviet army. During this time a field synagogue was erected in sight of the Wehrmacht. Only 12 Jews were handed over to their death by the Finnish Chief of Police.
} 
dren, they sometimes managed to stay together in the women's camp in Auschwitz-Birkenau (for however short a duration). As well as the elderly and infirm, mothers with young children were the most vulnerable of all those entering Auschwitz. By the summer of 1944 Hungarian Jewish babies and children were being torn from their mothers outside the crematoria and sent separately to the gas or burnt alive in a fire pit near the crematoria. So it should be clear from the outset that I am not suggesting that motherhood as such could withstand the Nazi genocide by some kind of supernatural or moral force. The forcible deportation of children under 10 from the Lodz ghetto on 10th September 1942, to the death camp at Chelmo gave ample evidence of the impotence of most mothers to save either themselves or their children.

Even having acknowledged the relative impotence of mothers (and fathers), a post-Holocaust theology should not continue to ignore the experience of those children's mothers and the theological possibilities of maternalist language and values. Maternal experience and the ethical difference that produces has been an important focus of second wave feminist scholarship. It is this, and Susan Sered's analysis of Jewish women's traditional concerns with "love, death and human relations" (1994, 169-190; 1996, 5-3), that contextualizes my situating the experiences and tropes of motherhood at the centre of the feminist theological enquiry in ways that will challenge, modify, and finally alter the character and substance of the post-Holocaust project. In particular, I am convinced that a feminist theological reading of women's narration of broken (and sometimes preserved or restored) familial relationships during the Holocaust shifts our conception of God's presence among European Jewry between 1933 and 1945.

Theological and other theorizations of the Holocaust are rightly preoccupied with brokenness, fragmentation, rupture and disappearance. Yet women survivor testimonies often construe and redeem loss through their sense of unbroken relational continuities with their mothers and foremothers. The narratives of more memoirs and testimonies than can be cited here are almost constituted by the story of the turbulent passage of the 
mother and daughter, or sister and sister relationship that, whether actual or adoptive, either survived or ended in the holocaustal period.

Giuliana Tedeschi particularly mourned the loss of a small bunch of dried violets that her daughter had picked for her grandmother in the Italian spring of 1944 and which had been taken from Tedeschi with her other belongings on arrival in Auschwitz $(1994,57)$. Here the female line was symbolised in the giving of flowers, by one generation of women to another. The dry, dead, crushed and, finally, vanished flowers evoke the withering, death and disappearance of countless maternal lines. But after the Holocaust, Charlotte Delbo could see a new baby as having been born on behalf of all those mothers who had died:

You remember this peasant woman, lying in the snow, dead with her newborn frozen between her thighs. My son was also that newborn [...] My son is their son, he belongs to all of them. He is the child they will not have had. (Delbo 1995, 261-262.)

Women survivors draw strength even from the memories of their mothers. This is more than apparent in the many women's memoirs of the Holocaust published in recent years (one thinks of those of, say, Trudi Berger 1992, Sara Tuvel Bernstein 1997, Rena Kornriech Gelissen 1996, Kitty Hart 1983, Clara Isaacman 1984 and Schoschana Rabinovici 2000. See further, Gurewitsch \& Weinberger 1999; Ritvo \& Plotkin 1998). It is the author's relation with her mother (whether living or dead) which gives meaning, purpose and substance to her survival and hence to the narration of her experience. Sisters, especially in the absence of a mother, similarly anchor meaning and hope. (Kornriech's memoir, for example, is shaped by the promise she made to her mother to protect her sister Danka, who, the physically weaker of the two, also helps Kornriech herself to survive Auschwitz.) Reading these narratives from a post-Holocaust feminist theological perspective (that is, without attributing a posthumous theology to women who cannot refuse it) it is as if within the story of Israel's relationship with the male father/king God, is another (untold) story: the story of the female bond of protective 
love between the mother-God and the daughters of Israel in extremis. If love is stronger than death (Song of Songs 8: 6) then so is maternal presence - a phenomenalizing of divine and human of love. ${ }^{3}$

These female Jewish bodies carry the historical process as an ark or tabernacle inside which is wrapped the story or Torah Jews have told about the relationship between themselves and God, and which unfolds and rolls on and out through time in the carrying and opening of the body to new life. And just as the Torah scrolls must be cherished, dressed, crowned with silver and cradled in our arms, so too must be each woman's (derelict) body, in Auschwitz on which desecrated scroll is inscribed another (not the last) chapter of the story of the love between God and Israel. I shall turn now to some of these body-stories within stories as midrashim on the love of God for Israel, the utmost sign of which was God's presence as (a) Mother in Auschwitz and other sites of holocaustal mass death.

All of the brief survivor narratives that can be found on Judy Weissenberg Cohen's web-site on the subject of women and the Holocaust demonstrate that maternal or quasi-maternal relations with other women were of ultimate concern. For example, alone in Bergen-Belsen, the sixteen-year-old Weissenberg Cohen herself asked the Feig sisters to adopt her as their Lagerschwester. They did so and proceeded to share all that they had. For Cohen, these women assumed some of the functions of a mother: "it was very important to know that someone cared whether you woke up in the morning". Elisabeth de Jong's account of surviving Auschwitz's human experimentation Block 10 also focuses on how the female doctor there would "gently wash and dress our wounds and try to console us" and how she herself struggled to keep her sister Lilian alive. Judith Rubenstein's two entries speak of little more than two women: the tragic manner in which her mother sacrificed her own life in Auschwitz to save that of Judith, and of the kindness and compassion of Ethel, a Blockälteste who "attempted to ease the pain" and also saved her

\footnotetext{
${ }^{3}$ This maternal and quasi-maternal physical solidarity can be seen in the photographs of the massacre at Lepajya in Latvia where Jewish women and girls stand together waiting for death, with their arms tightly linked, a child nestling into a woman's hips and separated from the men, in the freezing Baltic wind of December 1941.
} 
life. Irene Csillig, a Hungarian dressmaker, tells her story in such a way that all other experience is omitted from her narration except that of the preservation of her relationship with her mother and sister. Having survived a period in Auschwitz, her mother died in Stutthof; after liberation Csillig went back on a fruitless journey to their home town to find objects - a wedding ring and a petit-point embroidered cushion - that would remind her of her mother, or more, re-present her mother to her. Although these were not returned to her, like those of other women survivors, her account is at least partially resolved by its closing reassurance to the reader (common to the genre) that she has married and has had children and grandchildren. ${ }^{4}$ The maternal line, a covenant of trust between mothers and daughters, can go on into the future; grieving, consoling maternal love could take on the redemptive function and attribute of divine love.

In Judith Jaegarmann's testimony divine presence is knowable in the traditions of maternal love associated with Shekhinah - the traditionally female figure that hypostasises the divine presence in both traditional and feminist Judaism. In 1943, at the age of thirteen and from an Orthodox family, she was deported from Theresienstadt to Auschwitz. There her mother, described as a "guardian angel", continued to give her the courage to live. She offered motherly comfort to all the girls who were alone: "all the girls tried to stay near to her and felt sheltered by her". In the women's camp in Birkenau, Jaegarmann's mother tore her own blanket apart and made bands to protect her daughter's legs from the frostbite wrought by winter temperatures of minus twenty degrees centigrade. On one occasion, transported out of Auschwitz to another work camp, Jaegarmann lost consciousness while labouring in the snow. As in the moment of birth she opened her eyes to a circle of female faces above her:

Suddenly I felt as if someone wakes [sic] me and I saw the faces of many women over me. I overheard them saying "the little one almost froze to death". They let me lie down for a little while longer and then many girls

\footnotetext{
${ }^{4}$ Accessed November 19, 1999 on http://www.interlog.com/ mighty/'personal reflections'. See Cohen 2001.
} 
started massaging and rubbing me, so that I started to feel my body, hands and feet again. ${ }^{5}$

And yet women survivors' memoirs show that motherhood - whether as a socio-ethical posture or as a biological relationship - is not always an asymmetrical relation of care. During the Holocaust, care for children could give women themselves a sense of meaning, purpose and hope. When an orphaned, four-year old Jewish girl arrived at the house in Antwerp where Clara Isaacman and her mother were hiding, her mother's depressed, withdrawn face "lit up when she held the child on her lap, singing to her and combing her curls" (Isaacman 1984, 103). Often, the sustenance of children by mothers was reciprocated by children. Ghetto children sometimes worked for their mother's survival by finding food for them and tending them when they were sick (fathers and older brothers having been commonly separated from their families at an earlier stage of the genocide). Children could themselves become "mothers" where their own mothers had numerous children to care for. Isabella Leitner mourns her baby sister Potyo, who was probably thrown alive into the fire-pits of Auschwitz on May 31st 1944, as if she had been her own baby: "She was 'my' baby". Leitner had bathed her and changed her nappies as if she were Potyo's mother. Speaking as her mother might have done had she survived, Leitner writes: "She would be a middle-aged woman now, and I still can't deal with having lost her" $(1978,21)$.

Motherhood itself began to lose its usual relational contours as sisters took on the providential functions of mothers to one another, and mothers took on those of quasi-divine presence. Even in the days after liberation, Isabella Leitner's sister Rachel remained what she calls the "mother hen", sewing a cut-up blanket into a coat to keep her sister warm. Speaking for her sisters as well, Leitner writes to Rachel: “The endless care. The endless concern. Our complete confidence that we could rely on you. We always blessed you. Did you know that?" $(1978,81$.

\footnotetext{
${ }^{5}$ Accessed November 22, 1999 on http://www.interlog.com/ mighty/'personal reflections'. See Cohen 2001.
} 
Of course, the redemptive loading of maternal presence is now, and was at the time, not limited to biological mothers or even a female object. For the Warsaw ghetto orphans in Dr Janusz Korczac's care, "[w]hatever would happen, they were to know that it would not matter as long as he, the doctor, would be with them. All he asked was that they remain together. [...] And so the children set out on their journey [to the death camp, Treblinka]. [...] Nothing mattered, as long as the doctor was with them." (Zeitlin 1978, 56-57.) Korczac refused offers of rescue from the ghetto and of a personal reprieve at the time of his deportation. He chose to accompany the children and, on his now legendary "last walk" from the orphanage to the freight wagons, he is reputed to have carried the two smallest children in his arms - this, despite his failing health, swollen feet, and the children who walked close to his side (Mortkowicz Olczakowa 1985, 135). A similarly "maternal" attitude can be found among Hasidic men, the physical presence of whose Rebbe offered not only religious teaching, but calming words, counsel, consolation and a practical support that was reciprocated by his followers. Among numerous possible examples is the Komarner Rebbe, Rabbi Baruch Safrin, who refused two offers of rescue, insisting that he remained with his followers in their distress. The Paizesner Rebbe also refused to abandon his Hasidim, stating: "Wherever my Hasidim are, there I shall be as well." The Slonimer Rebbe knew that he might have been mistaken in refusing to leave Barenowich, but said: "What can I do when my little children [his Hasidim] are dependent upon me?" (Schindler 1990, 74-79.)

While it can be seen as a mark of the tzaddik or saint for a Jewish man to take on the "feminine" burdens of motherhood or the maternal posture (see further Raphael 2001), it can be difficult for Anglophone Jewish women over the age of forty not to read Jewish motherhood through the stereotypes of their own times, especially that of Jewish-American caricature (the most excessive being that of Sophie in Philip Roth's puerile 1967 Portnoy's Complaint). Even after the Holocaust had consumed so many of them, the Ashkenazic Yiddishe mama was something of a comic turn. An ambivalent object of both derision and sentimental yearning, she was a smothering, over-protective, 
over-feeding emasculator of sons; a woman who was ageing into the fussing, needy "old" woman for which Yiddish has numerous derogatory terms: yidneh, yenta and yachne being some of them (Rosten 1968, 451, 436-437, 433 respectively). The contemporary Jewish mother is no longer caricatured as the (now somewhat dated) Yiddishe mama but - if she is prosperous enough - a materialistic, flashy, over-dressed, selfish "Jewish Princess" or Californian Jewish "Valley Girl" who is a lot less interested in children than in her designer wardrobe (Belzer 2001; Antler 1997; Moskowitz 1995). That caricature is worthy of study in itself, but infinitely more theologically interesting, however, is the mama of the eastern European shtetl, who, taken seriously as a necessarily resourceful woman who often earned the wages to feed and clothe her family, can become a symbol of strength and responsibility: a very good image of divine providence. ${ }^{6}$ Etty Hillesum describes one such mother in the desperate conditions of the Westerbork transit camp. The woman's husband and two elder sons had been deported. Herself starving, the mother had seven children left to care for as she made ready for her own deportation from Holland to Auschwitz. Hillesum writes:

She bustles about [...] she's busy, she has a kind word for everyone who goes by. A plain dumpy ghetto woman with greasy black hair and little short legs. She has a shabby, short-sleeved dress on, which I can imagine her wearing when she used to stand behind the washtub, back in Jodenbreestraat. And now she is off to Poland in the same old dress, a three day's journey with seven children. "That's right, seven children, and they need a proper mother, believe me!" $(1988,132$.

During the Holocaust, motherhood was, in Katharina von Kellenbach's view, as much a form of resistance as armed revolt. Those seeking to understand Jewry's struggle for spiritual and material survival should not overlook

\footnotetext{
${ }^{6}$ Asphodel Long notes the necessary energy, intelligence, resourcefulness and dependability of the Anglo-Jewish immigrant mother of the early twentieth century. Long's mother ran a small shop, took care of her children and did all the housework. Her father "(like many immigrants) expected a woman to do everything, including make the money. He expected to sit and daven, go out with his mates and pretend to be learned but really, as far as I can make out, just do nothing in particular." (Long 1989, 190.)
} 
women's reproductive labour. In hope and faith couples partook in a tradition of resistance to genocidal persecution dating back to the time of Moses: they chose to have children at the least auspicious of moments and when most couples were aware that the mother could face caring for the child destitute and facing her persecutors alone. (1999, 19-32.)

Israel too is that fatherless child for whom the Mother-God is covenanted to take responsibility and to share or take away its pain. But Israel is also, like all children, covenanted through the reciprocities of love to take increasing responsibility for the world given it by God. The Holocaust imposed a complex set of maternal and quasi-maternal responsibilities. We have already seen that maternal obligations often had to be reciprocated by children prematurely matured by danger and need. Mothers had responsibilities not only to their children but also to their elderly parents. This traditional duty of daughterly care further endangered women's lives; had it not been that women felt that they could not leave their parents to an unknown fate, many could have escaped before emigration became impossible. Lucie Adelsberger, for example, refused to leave her elderly mother in Germany. Although offered a visa for the United States for herself, she could not obtain one for her mother (Adelsberger 1996, 12).

Women's friendships could also entail mothering. Mothers mothered mothers in Auschwitz. Lying in her bunk and in great distress, Giuliana Tedeschi's sriend Zilly held Tedeschi's hand in her own "small, warm, hand". Zilly pulled the blanket around Tedeschi's shoulders and in a "calm, motherly voice" whispered in her ear: "Good night dear-I have a daughter your age!" Sleep then "crept slowly into [her] being along with the trust that hand communicated, like blood flowing along the veins". (Tedeschi 1994, 9-10.) Or again, Charlotte Delbo used to hold her friend Germaine's hand in Auschwitz to help her get to sleep. Germaine later says: “Do you recall how you used to say, in Auschwitz, 'Let me hold your hand so I'll fall asleep. You have my mother's hands.' Do you remember saying that, Charlotte?" (Delbo 1995, 310.) Once voiced in the promise of Ruth to her mother-in-law Naomi that she will go where Naomi goes, where Naomi dies she shall die; 
that nothing but death shall part her from Naomi (Ruth 1:16-17), it may be that maternal presence in its multiple forms and surrogates offers a different means to trust in God than those tradition has accustomed us to.

This is not to lapse into cliché: mothers are often bored, irritated and angered by their children. Not all mothers and children like one another. Some children are frightened of their mothers. And nor are mothers and their children immunised by love. During the Holocaust, maternal power (more a fancy of nineteenth-century social and religious rhetoricians than a material force) could become an ever more necessary fiction; a way of suspending disbelief. Clara Isaacman's memories of hiding from the Nazis in occupied Belgium are illustrative of my point. During their two and a half years in hiding, Isaacman's mother would hold and comfort her, speaking confidently and with conviction of their future. It was only when the war was over that Isaacman wondered whether her mother had ever really believed her own reassurances (Isaacman 1984, 37; cf. Olczakowa's account of Korczac's assuring his children of a future in which he does not believe $1985,135)$. Isaacman recalls how the expression of love had become ritualised; almost a performance of sympathetic magic. Mothers would hold their children before the latter went out on dangerous errands, willing that, if nothing else, their love would protect them (Isaacman 1984, 60). Sometimes the "strong wishing" worked and children might often not have survived were it not for the love and proximity of their parents (Isaacman 1984, 97). And even when, in the great majority of cases, children did not survive, their end could be eased by a fiction that maternal or quasi-maternal presence would be their redemption. ${ }^{7}$

When God calls to Abraham, Jacob and Moses they answer, hinneni "I am here" or "here I am" (Gen. 22: 1; 31: 11; 46: 2; Ex. 3: 4; see also Is. 6: 8; cf. Cohen 1993, 95). For Emmanuel Levinas this "I am here" is the meaning of love $(1981,113,147)$. This is also the meaning of the commandment of love between God and persons; and the commandment to love both our neighbour and the stranger. Therefore to ask the question of God's presence

\footnotetext{
${ }^{7}$ Cf. André Schwartz-Bart's fictional account of this phenomenon in his novel, The Last of the Just. (1962, 337-345.)
} 
during the Holocaust is not only to ask "how was God made present to us?" but also, and inseparably from that, "how did we make ourselves present to God?" There is no divine presence without human presence - the hinneni or "Here I am". Presence is transitive; God cannot be present to nothing and nowhere. Just as a mother murmurs, "Mummy's here", when her child cries out in the night or when he is afraid because he cannot see her, to say "here I am" is to say here with you I am; my being human is to find and be present to you; here, in a place, answering you.

This is a dying and deathless love that is, for me, emblematised when Ferderber-Salz and other women had to remove corpses from the graves and burn them before the liberating army reached the camp. There they sometimes found two bodies: "a mother and a child, locked in an eternal embrace, since the mother had tried to protect the child with her body. The murderers' bullets had passed through the mother's body and entered her child's, killing both of them together." (Ferderber-Salz 1980, 102.)

Maternal kindnesses and attention to suffering also encapsulates the relational dynamic of the theology I have wanted to outline so briefly here, where kindness is not to be reduced to an ineffectual gesture or to a demeanour cherished only by children, but, in this situation, where all gestures against Nazism were more or less materially ineffectual, was the maternal quality of divine love. To be a mother of babies or young children is to be entirely vulnerable, with them, to harm at the same time as it is to be presentative of a mighty love which, as refuge, takes and holds its object within and against itself. This is the love of a Mother-God, known to tradition as (the) Shekhinah, and recently voiced by Penina Adelman's liturgical words: "I give praise to you, HaMakom, the Place of Power. Shekhinah, in the darkness of Your Womb we find comfort and protection. Rakhameima, Mother of Compassion, in the Darkness of Your Hidden Place we find the Source and the Power." (Adelman 1994, 165.)

Where the metaphor of a Mother-God represents not merely an aspect of God, but a function of God that reconfigures the entire concept of God, then the figure of the mother, bereaved and bereft of her children or remaining 
with her daughters in Auschwitz assumes a particular theological poignancy. For most Jewish feminists, "The Holy One is Gaol-tanu, Ima-ha-olam, our Redeemer, Mother of the World. She is Ha raham-aima, Compassionate Giver of Life. She is Makor hahaiim, Source of Life. She is our neighbourly spirit, the Shekhinah." (Broner with Nimrod 1993, 12.) In Jewish feminist liturgy, drawing on the maternal imagery found in the Hebrew Bible (Ps 22; Is. 46).

Blessed is She who in the beginning, gave birth [...]

Blessed is She whose womb covers the earth.

Blessed is She whose womb protects all creatures [...]

(Janowitz \& Wenig 1992, 176.)

Contemporary Jewish feminist liturgy widely expresses the faith that, "the Lord is warmth/She will cradle me. The Wings of the Lord will cover me. Her breath will soothe me." (Maggie Wenig, cited in Blumenthal 1993, 79.) There are, in short, important inter-textual connections to be made between scriptural words, these contemporary words and women's words about Auschwitz where the meaning and purpose of Jewish motherhood was to be destroyed and where pregnancy - the motherhood of an unborn child - could not be declared. Much Jewish feminism has insisted that the motherhood of God is the undeclared, untold story still unborn from the body of Israel and it seems necessary to bring these narratives of maternal disappearance together and to reflect upon them without confusing their historical reasons.

Narratives of maternal presence and disappearance thread their way through women's Holocaust memoirs, whether they write as mothers of hidden children, of children struggling to survive, of dead children, or whether they write as daughters with, or longing for, their mothers. As I read it, this narrative corpus is both a historical and a theological commentary on presence and absence; appearance and disappearance. In these stories and fragments of stories, the face of Shekhinah shines dimly, almost imperceptibly, through the smoke clouds of Auschwitz. Hers was a countenance figured 
by the tremendum of divine maternal wrath at the despoilation of her love, Israel, and the fascinans of her longing, seeking and calling to what was disappearing - literally going up in smoke - before her. God weeps with Rachel for her children who are gone (Jer. 31:15). ${ }^{8}$ It is worth remembering that in rabbinic and mystical tradition the kiss of the Shekhinah is the kiss of death, where God bends over the dying and gently extinguishes the spark of life in a consummation of love that is at once erotic and maternal. ${ }^{9}$ But that kiss was a redemptive one in so far as divine love and the human love that performs divine love pays a self-sacrificial price of (sometimes futile) labour and grief whose visible affliction is a moment of revelation. As recognised by Simone Weil - a Jew writing, unbaptised, on the margins of Christian tradition - experience can most fully reveal divine love when it is most painful. Affliction (malheur) has a revelatory power. Suffering is not itself redemptive but the visual tableaux of maternal grief offer both a recapitulation and prolepsis of God's redemptive act which is to bear witness to evil in her wrathful grief; ${ }^{10}$ a grief whose tremendum betokens the cosmic reversal that turns death to life: the resurrection event that is and has always been a classic tenet of Jewish faith.

\footnotetext{
${ }^{8}$ Here, I am assisted by meditation on Michelangelo's sculpture of the Pietà. For me, this is another image of a Jewish mother cradling her murdered son, here as if he were still a child in her lap. The Pietà, a Christian image, can be a revelatory image for Jewish women in so far as it represents a moment of Jewish abjection taken up into the sphere of redemption; the Jewish mother's grief presents a spectacle that stands in prophetic judgement on the world, and commanding its restoration to glory as that which was first imagined, created and loved by God.

${ }^{9}$ See Num 33:38; Deut 34:5. In the Bible, Moses, Aaron and Miriam die by the mouth of the Lord. Medieval rabbis occasionally developed this notion as a metaphor to describe the attainment of spiritual perfection.

${ }^{10}$ For a Jewish theology of the visual spectacle see Raphael 2006.
} 
Bibliography

\section{Adelman, Penina V.}

1994 A Drink from Miriam's Cup: Invention of Tradition among Jewish Women. - Journal of Feminist Studies in Religion 2, 151-166.

\section{Adelsberger, Lucie}

1996 Auschwitz: A Doctor's Story. Trans. Susan Ray. London: Robson Books.

Antler, Joyce (ed.)

1997 Talking Back: Images of Jewish Women in American Popular Culture. Brandeis, Waltham, Mass.: Brandeis University Press.

\section{Belzer, Tobin}

2001 On Being a Jewish Feminist Valley Girl. - Danya Ruttenberg (ed.), Yentl's Revenge: The Next Wave of Jewish Feminism, 181-188. New York: Seal Press.

\section{Berger, Trudi \& Jeffrey M. Green}

1992 A Daughter's Gift of Love: A Holocaust Memoir. Philadelphia: Jewish Publication Society.

Bernstein, Sara Tuvel \& Louise Toots Thornten \& Marlene Bernst Samuels

1997 The Seamstress: A Memoir of Survival. New York: Putnam Publishing Group.

\section{Blumenthal, David}

1993 Facing the Abusing God: A Theology of Protest. Louisville, Kentucky: Westminster/John Knox Press.

\section{Broner, Esther M. with Naomi Nimrod}

1993 The Women's Haggadah. New York: HarperSanFrancisco.

Cohen, Arthur A.

1993 The Tremendum: a Theological Interpretation of the Holocaust. New York: Continuum.

Cohen, Judith

2001 Women and the Holocaust. Personal reflections. [http:// www.theverylongview.com/WATH/ ]

\section{Delbo, Charlotte}

1995 Auschwitz and After. Trans. R. C. Lamont. New Haven: Yale University Press.

\section{Ferderber-Salz, Bertha}

1980 And the Sun Kept Shining... New York: Holocaust Library. 
Gelissen, Rena Kornriech with Heather Dune MacAdam

1996 Rena's Promise: A Story of Sisters in Auschwitz. Boston: Beacon Press.

Gurewitsch, Brana \& Leon J. Weinberger (eds.)

1999 Mothers, Sisters, Resisters: Oral Histories of Women Who Survived the Holocaust. Tuscaloosa: University of Alabama Press.

Hart, Kitty

1983 Return to Auschwitz. London: Granada Publishing.

Hillesum, Etty

1988 Letters from Westerbork. Trans. Arnold J. Pomerans. London: Grafton Books.

\section{Isaacman, Clara}

1984 Clara's Story as told to Joan Grossman. Philadelphia: The Jewish Publication Society of America.

Janowitz, Naomi \& Maggie Wenig

1992 Sabbath Prayers for Women. - Carol P. Christ \& Judith Plaskow (eds), Womanspirit Rising: A Feminist Reader in Religion, 174-178. New York: HarperSanFrancisco.

Kellenbach, Katharina von

1999 Reproduction and Resistance during the Holocaust. - Esther Fuchs (ed.), Women and the Holocaust, Narrative and Representation (Studies in the Shoah, vol. Xxii), 19-32. Lanham, Maryland: University Press of America.

Leitner, Isabella \& Irving A. Leitner (eds)

1978 Fragments of Isabella: A Memoir of Auschwitz. New York: Thomas Y. Crowell.

\section{Levinas, Emmanuel}

1981 Otherwise than Being, or Beyond Essence. Trans. Alphonso Lingis. The Hague: Martinus Nijhoff.

\section{Long, Asphodel}

1989 A Pinhole in the Darkness. Interviewed and edited by Ruth Swirsky. - Jeanette Copperman \& Hannah Kanter \& Judy Keiner \& Ruth Swirsky (eds), Generations of Memories: Voices of Jewish Women. London: The Women's Press.

Moskowitz, Faye (ed.)

1995 Her Face in the Mirror: Jewish Women on Mothers and Daughters. Boston: Beacon Press.

Olczakowa, Hanna Mortkowicz

1985 Janosz Korczak's Last Walk. - Jacob Glatstein \& Israel Knox \& Samuel 
Margoshes (eds). Anthology of Holocaust Literature, 134-136. New York: Atheneum.

\section{Rabinovici, Schoschana \& Mirjam Pressler \& James Skofield}

2000 Thanks to My Mother. Trans. Shoshanah Rabinovits. London: Puffin.

\section{Raphael, Melissa}

2001 The Face of God in Every Generation: Jewish Feminist Spirituality and the Legend of the Thirty-Six Hidden Saints. - Ursula King (ed.), Spirituality and Society in the New Millennium, 234-246. Brighton: Sussex Academic Press.

2003 The Female Face of God in Auschwitz: A Jewish Feminist Theology of the Holocaust. London and New York: Routledge.

2006 The Mystery of the Slashed Nose and the Empty Box: Towards a Theology of Jewish Art. - Journal of Modern Jewish Studies 5, 1-19.

\section{Ritvo, Roger A. \& Diane M. Plotkin}

1998 Sisters in Sorrow: Voices of Care in the Holocaust. Austin: Texas University Press.

\section{Rosten, Leo}

1968 The Joys of Yiddish. Harmondsworth, Middx: Penguin Books.

\section{Roth, Philip}

1986 [1967] Portnoy's Complaint. Harmondsworth, Middx.: Penguin.

\section{Schindler, Pesach}

1990 Hasidic Responses to the Holocaust in the Light of Hasidic Thought. New Jersey: Ktav Publishing House.

\section{Schwartz-Bart, André}

1962 The Last of the Just. Trans. Stephen Becker. London: Secker \& Warburg.

\section{Sered, Susan Starr}

1994 "She Perceives Her Work to Be Rewarding", Jewish Women in a Cross-Cultural Perspective. - Lynn Davidman \& Shelly Tenenbaum (eds), Feminist Perspectives on Jewish Studies, 169-190. New Haven: Yale University Press.

1996 Mother Love, Child Death and Religious Innovation: A Feminist Perspective. - Journal of Feminist Studies in Religion 12, 5-23.

\section{Tec, Nechama}

2003 Resilience and Courage: Women, Men, and the Holocaust. New Haven and London: Yale University Press.

\section{Tedeschi, Giuliana}

1994 There Is a Place on Earth: A Woman in Birkenau. Trans. Tim Parks. London: Minerva. 


\section{Zeitlin, Aaron}

1978 The Last Walk of Janusz Korczak. Trans. Hadassah Rosensaft and Gertrude Hirschler - Janusz Korczak, Ghetto Diary. Trans. Jerzy Bachrach and Barbara Krzywicka. New York: Holocaust Library. 